\title{
RÖSNITZ/ROZUMICE. POLIFONICZNOŚĆ GÓRNOŚLĄSKIEJ TRADYCJI PROTESTANCKIEJ
}

Miejscem pamięci, które w roku jubileuszu 500-lecia reformacji warto przypomnieć, a właściwie wydobyć z niepamięci, jest mała miejscowość położona na południu Opolszczyzny, na samej granicy z Republiką Czeską o nazwie Rozumice, której niemiecka nazwa brzmi - Rösnitz. W odniesieniu do przeszłości tym miejscem pamięci jest społeczność Rösnitz, która niemal w całości była wyznania luterańskiego do roku 1946, do dnia, w którym zostali mieszkańcy tej wioski wypędzeni. Dziś symbolem tej ewangelickiej przeszłości jest ruina kościoła, której budowę ukończono w 1807 roku, świątynia ta powstała na fundamentach średniowiecznego kościoła.

Zanim autor wyjaśnieni dalszą część tytułu tego tekstu jeszcze należy wrócić do samego terminu „miejsca pamięci”, który wprowadził do nauk historycznych Pierre Norra ${ }^{1}$. Termin ten jest dziś szczególnie popularny, jego kariera powinna być przedmiotem głębszego namysłu ${ }^{2}$. Autor tego terminu nigdy go nie zdefiniował. $\mathrm{Na}$ początku lat siedemdziesiątych XX wieku zachęcał do podjęcia badan nad lieux de mémoire („miejscami pamięci”) i rozumiał go wtedy głównie ,jako zinstytucjonalizowane formy wspomnień przeszłości. »Miejscami pamięci« mogło być dla niego zarówno archiwum historyczne czy pomnik bohatera, jak i mieszkanie prywatne, w którym spotykają się zazwyczaj kombatanci, by obchodzić uroczystości z powodu jakiejś ważnej dla nich rocznicy"3. W Les lieux de mémoire (Paris 1984) „miejsca pamięci” rozumiane są jako depozytariusze przeszłości, których badanie przypomina rozpoznawanie treści dzieł sztuki. Nora uczulał badaczy, by badać

\footnotetext{
* DR HAB. KRZYSZTOF GŁADKOwSKI - Uniwersytet Warmińsko-Mazurski w Olsztynie, e-mail: krzysztof.gladkowski@uwm.edu.pl.

${ }^{1}$ P. Nora, Mémoire collective, w: Faire de l'histoire, sous la dir. de J. Le Goff, P. Nora, Paris 1974, s. 401: „Szłoby tu - pisze Nora - o miejsce w dosłownym znaczeniu tego słowa, w którym pewne społeczności, jakżeby one nie były - naród, grupa etniczna, partia - składają swoje wspomnienia lub uważają je za nieodłączną część swojej osobowości”; cyt. za A. Szpociński, Miejsca pamięci (lieux de mémoire), „Teksty Drugie”, 2008, nr 4, s. 12; wersja elektroniczna: www.ceeol.com.

${ }^{2}$ Zob. A. Szpociński, dz. cyt., s. 11.

3 Tamże, s. 12.
} 
niedostrzegane miejsca, których przeszłość przy uruchomionej wyobraźni można badać w kodeksach, kronikach, przepisach prawnych, języku, sztuce, poezji. Przy takim podejściu materialność miejsc jest sprawą drugorzędną. „Miejsce” w tym wypadku może być rozumiane metaforycznie, ,jako jakiekolwiek znaki i symbole, które skupiają na sobie uwagę, ponieważ podejrzewa się, że są depozytariuszami przeszłości [...] realnym (mauzoleom, pomnikom, archiwom, świątyniom itd.), jak i metaforycznym »miejscom pamięci« przysługują te same właściwości: są one własnością określonych grup społecznych i skrywają w sobie takie lub inne, ważne z punktu widzenia zbiorowości (idee, normy, wzory zachowań). Różnice między nimi polega na tym, że w pierwszym wypadku »własność« rozumiana jest dosłownie, w drugim metaforycznie, w pierwszym oznacza »fizyczną« możliwość nawiedzenia określonych miejsc, w drugim możliwość powoływania się na nie jako na własną przeszłość"'. Metafora „miejsca”, niczym miejsca, gdzie prowadzi się wykopaliska, zachęciła do prowadzenia badań, których zakres wydaje się nieskończony i pozwala na odkrycia rzeczy i treści dotąd zakrytych i nieznanych.

To szerokie rozumienie terminu „miejsca pamięci” pozwala autorowi pracy na opowiedzenie o swojej przygodzie z poznawaniem przeszłości luterańskiej społeczności Rösnitz. Zwykle sądzimy, że słowo „protestantyzm” oznacza zachodnią gałąź chrześcijaństwa, która odłączyła się od Kościoła rzymskiego w okresie reformacji. W Polsce słowo „protestantyzm” i słowo „luteranizm” są często używane synonimicznie. To już w Niemczech nie jest możliwe, gdyż tu są odróżniane m.in. luteranizm i kalwinizm, i słowo protestantyzm nie może jednoznacznie oznaczać jednej z tych społeczności. W Polsce obecność członków społeczności Kościoła reformowanego jest niemal nie dostrzegana, stąd identyfikuje się Kościół ewangelicko-augsburski z protestantyzmem. Nie zagłębiając się w historię obu tych gałęzi, które wewnętrznie też są zróżnicowane, należy przejść do „polifoniczności” tradycji luterańskiej w jednym miejscu, którym jest miejscowość Rozumice, a ściśle są nimi jej dawni mieszkańcy.

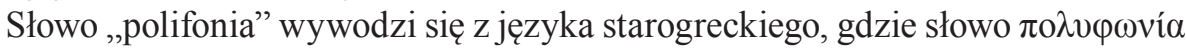
(polyphonia) oznacza „wiele głosów”. W muzyce oznacza rodzaj faktury muzycznej, w której równocześnie dwa lub więcej głosów prowadzonych jest niezależnie od siebie. Przez „polifoniczność” w literaturze z kolei rozumie się utwór „wielogłosowy", w którym postaci czy idee są samodzielne i równouprawnione. Jednak nazwa „utwór polifoniczny” wywodzi się z muzyki. W technice kompozytorskiej polifoniczność jest łączeniem $\mathrm{w}$ jednobrzmiącą linię różnych melodii. W powieści polifoniczność to m.in. ukazanie postaci w jej chaosie i nieforemności. Za klasyczny przykład takiej powieści uchodzi Zbrodnia i kara Dostojewskiego, który pisał: „Zmusić wiele głosów, aby dźwięczały razem, tak aby przy ogólnym wrażeniu muzyki jako całości, jako utworu, żaden głos nie tracił swojego wyrazu, swojego dramatycznego znaczenia, pozostając całkowicie wiernym swej dramatycznej

\footnotetext{
${ }^{4}$ Tamże, s. 15.
} 
prawdzie" . W naszym wypadku chcemy ukazać jedną społeczność, która w ciągu swojej historii od momentu przyjęcia luteranizmu przeżywała rozterki związane z różnymi duchowymi ścieżkami, na które wstępowali jej członkowie. Wprawdzie w tytule swojego referatu autor umieścił określenie „tradycja protestancka”, jednak najpełniej wyraża historię tej społeczności określenie „tradycja chrześcijańska”, gdyż mamy w tym wypadku do czynienia z udokumentowaną obecnością wyznania katolickiego, luterańskiego, Jednoty Braterskiej w postaci herrnhuterskiej (znanej jako bracia morawscy) oraz pietyzmu, z kolei przed i w czasie II wojny światowej - Deutsche Christen (Niemieccy Chrześcijanie) i Bekennede Kirche (Kościół Wyznający). A symbolem tej długiej historii jest dziś ruina kościoła ewangelickiego w Rozumicach.

To miejsce pamięci zasługuje na szczególną uwagę, gdyż jest świadectwem trwania tradycji luterańskiej, jak zaznaczono w tytule polifonicznej. Obok kościoła, lecz z jego historią ściśle związane miejsca pamięci to Kanzel (ambona w lesie), dzwon w kościele ewangelickim w Ściborzycach Wielkich i drugi dzwon w Ahlen-Vorhelm w Niemczech i wreszcie nieobecne już krajobrazie lokalnym krzyże.

Historyczne wzmianki o Rozumicach sięgają XIV stulecia. Przypuszczalnie już wtedy mieszkali tu sprowadzeni z Niemiec, dokładnie z Frankonii osadnicy. Byli katolikami nominalnie. Co jednak drążyło ich dusze nie wiemy, nie posiadamy do tego stosowanych dokumentów i świadectw. Mamy jednak zapisy w miejscowych kronikach, świadczące o prereformacyjnych prądach, które przez kontakt za społecznością następców Jana Husa - braćmi morawskimi - mogą wskazywać, iż świadomość religijna mieszkańców Rösnitz ukształtowana została na sposób reformacyjny już przed przybyciem ich z Frankonii. Ślad wierzeń waldensów w Rozumicach zachęca do wzięcia pod uwagę tej ewentualnej ścieżki, prowadzącej do wyjaśnienia potwierdzonych już przez tradycję lokalną kontaktów rozumiczan z braćmi morawskimi, a przez nich z tradycją waldensów w XV stuleciu. Waldensi byli aktywni w południowych Czechach, a ich działalność niewątpliwie wpłynęła na myśl reformacyjną zarówno husycką, jak i luterańską. Powoduje to, że można (a nawet należy poważnie potraktować) postawić hipotezę, że społeczność Rösnitz odzwierciedla duchowość, którą kształtował okres prereformacyjny, stąd $\mathrm{w}$ jej historii obecne były napięcia wynikające $\mathrm{z}$ duchowych potrzeb członków tej wspólnoty.

Autor pierwszej publikacji poświęconej historii ewangelickiego kościoła w Rozumicach zafascynowany był historią tej społeczności, którą poznał m.in. z miejscowej kroniki kościoła (Kirchenchronik) oraz gminy (Gemeindechronik). W przedmowie wyraził przypuszczenie, że jest to wyjątkowa społeczność, gdy idzie o wierność wyznaniu ewangelickiemu: ,[...] sie sollen endlich die in der oberschlesischen Kirchengeschichte vielleicht einzig dastehende Standhaftigkeit in evangelischen

\footnotetext{
${ }^{5}$ F. Dostojewski, Zbrodnia i kara,
} 
Bekenntnis [...]"으 (są oni w końcu w górnośląskiej historii Kościoła może wyjątkowym [świadectwem] wytrwałości w ewangelickim wyznaniu). Ta wyjątkowość jest motywem, dla którego w roku jubileuszu reformacji, chcemy zwrócić uwagę na dziedzictwo kulturowe, którego spadkobiercami jesteśmy.

Rozumiczanie już przed reformacją mieli swój kościół (istniał w 1430 roku) i chociaż u schyłku XV stulecia w nabożeństwach panowały tu katolickie zwyczaje, to przez kontakty handlowe z Opawą nawiązali stosunki z braćmi morawskimi, którzy tu żyli w ukryciu i nauczali. Kontakty te były na tyle silne, że miejscowa tradycja uznała, że Rozumice były ewangelickie przed luteranizmem i ich umysły były przygotowane na dzieło, które wyszło w 1517 roku z Wittenbergii?. Tradycja ustna przyjęła, iż już w roku 1524 był tu luterański kaznodzieja, a w 1526 roku nie było żadnego katolika w Rozumicach. Przyjęcie luterańskiego wyznania związane było zapewne z zakupem Księstwa Karniowskiego (Krnowskiego) przez Georga Hohenzollerna $^{8}$ w roku 1523. Obecność luterańskiego księdza w Rozumicach jest historycznie potwierdzona w roku $1577^{9}$. Rozwój tej luterańskiej społeczności przebiegał w sposób niezakłócony do czasu wojny trzydziestoletniej, gdy to Księstwo Karniowskie utracił margraf Johan Georg, a księstwo przypadło Lichtensteinom, którzy rozpoczęli siłą przywracać katolicyzm. W Rozumicach przed Bożym Narodzeniem w 1628 roku Kościół zamknięto i zmuszono miejscowego księdza Raphaela Ancklara, by z rodziną opuścił Rozumice. Kościół był zamknięty do roku 1646. Wierni zbierali się pod kościołem na modlitwie i śpiewach religijnych.

${ }^{6}$ M. Fiebig, Geschichte der Ewangelischen Kirche zu Rösnitz $(\mathrm{O}=\mathrm{S}$.) nebst Mitteilungen [ber Pfarrei, Schule und sonstige wichtige Vorgänge allgemeinerer Art aus dem Leben der Heimat. Zur Feier des hundertjährigen Kirchenweihjubiläums am 18 October 1907 der jubilierenden Gemeinde gewidmet von ihrem Pfarramt, Rösnitz 1907, s. 6.

7 O ewangelickim usposobieniu mieszkańców Rösnitz (Rozumic) wynikającym z działalności Matthiasa z Kunewaldu, który w 1467 roku został wyświęcony na biskupa braci morawskich przez Stefana, biskupa waldensów, informuje tekst zatytułowany Die Geschichte der evangelischen Kirche zu Rösnitz bei Troppau, opublikowany we „Fliegende Blätter für den Aufbau Zions in der Diaspora” 1863, Nr 1, s. 6, oraz „Bausteine für den Aufbau Zions. Monatsschrift für evangelische Gemeinden” 1864 (Dezember), s. 94. Oba teksty znajdują się w Evangelisches Zentralarchiv in Berlin (EZA5071/12) Signatur: EZA 200/ 1 /4490, karty: D. 75 R i D. 107 R. Dziękuję w tym miejscu księdzu Marcinowi Undasowi za udostępnie kopii tych archiwaliów. Tekst ten jednocześnie przypisuje zasługi w rozszerzeniu zbawiennego dzieła Janowi Ámosowi Komenský’emu (Comeniusowi).

${ }^{8}$ Georg der Fromme (Jerzy Pobożny) był synem Fryderyka Hohenzollerna, margrabiego brandenburskiego na Ansbach i Zofii Jagiellonki, po śmierci Fryderyka był margrabią Ansbach-Brandenburg-Kulmbach (1484-1543), księciem karniowskim, panem na Bytomiu, księciem raciborskim. Przydomek „Pobożny” zyskał już za życia, przypuszczalnie jako gorliwy protestant, który na sejmie w Augsburgu w 1530 r. miał powiedzieć do cesarza: „złożył bym raczej głowę pod topór katowski, niżby odstąpił od słowa Bożego”. H. Eberlin, Schlesische Kirchengeschichte, Bd. I. Das Evangelische Schlesien, 3. Aufl., Verlag der Schlesischen Evangelischen Zentralstelle, Goslar 1952, s. 52. Zob. też K. Kreßel, Die Reformation in Ansbach, w: H. Sommer (hrsg.), Es geschah im Namen des Glaubens. Evangelisch in Dekanat Ansbach, Verlag der Ev.-Luth. Mission, Erlangen 1991, s. 18.

${ }_{9}$ Por. Fiebig, dz. cyt., s. 10; F. G. E. Anders, Statistik der Evangelischen Kirche in Schlesien nebst eine Kirchen-Carte, Wilhelm Gottlieb Korn, Breslau 1848, s. 670. 
W roku 1634 ufundowali dzwon, chociaż nie mógł on ich wzywać na nabożeństwa w kościele, nosił on na swym płaszczu napis: „Ich freue mich deß, daß mir geredet ist, daß wir werden in das Haus des herrn gehenn” („Uradowałem się, że mi powiedziano, że pójdziemy do domu Pana"). Ten tekst pochodzący z Psalmu 122, 1 był proroczy, gdyż w Poniedziałek Wielkanocny, 2 kwietnia 1646 roku, jeszcze przed zakończeniem wojny trzydziestoletniej kościół otwarto ${ }^{10}$. Dla niewielu ocalałych od zarazy, miecza i głodu ewangelików rok 1646 był znakiem powrotu wolności wiary, który jak chce miejscowa tradycja poprzedziło (w 1644 roku) cudowne wydarzenie w zamkniętym dla ewangelików miejscowym kościele ${ }^{11}$. W dniu otworzenia kościoła miejscowy nauczyciel (Schulmeister), pochodzący z Altdorff pod Norymbergą, Carolus Fast odczytał kazanie z nowej postylli Johanna Heermanna. Wspominamy tego śląskiego pastora poetę, gdyż w jego twórczości dostrzeżono wątek pietystyczny ${ }^{12}$, a do pietystów przyjdzie nam jeszcze powrócić.

Wprawdzie kościół został udostępniony i rozpoczęto w nim praktyki religijne, jednak nie trwało to długo. Wbrew postanowieniom traktatu westfalskiego odmówiono luteranom prawa do praktyk religijnych w cesarstwie habsburskim. Ludność zaczęła masowo opuszczać swoje miejscowości udając się do księstw, w których takie praktyki były możliwe ${ }^{13}$. W Rozumicach mimo zabiegów właściciela ziem, do którego należały też Rozumice i oporu mieszkańców kościół siłą przekazano w administrację księdza katolickiego z Pilszcza w 1659 roku i zakazano w nim nauczania, potem kościołem administrował ksiądz z Oldřišova, a 10 maja 1671 roku przemocą wprowadzono ojca jezuitę do kościoła w Rozumicach, łamiąc prawa patronackie ${ }^{14}$. Miejscowi luteranie starali się to uniemożliwić i zostali aresztowani. Wypuszczono ich dopiero, gdy społeczność Rozumic spełniła warunki wyznaczone

${ }^{10} \mathrm{~W}$ tradycji ustnej przechował się zapis prawdziwego (gründliche und wahrhaftige) wydarzenia, które przydarzyło się w 1644 roku Hansowi Laske. Anioł miał mu we śnie ukazać niebiański raju, gdzie widział Boga i Jezusa, a także zobaczył piekło. 2 lipca 1644 roku w święto Nawiedzenia Najświętszej Marii Panny ludność Rozumic zaskoczył głos dzwonów. Gdy ludzie dotarli pod kościół zobaczyli przez okna, że w jego wnętrzu znajduje się Hans, który w zamkniętym kościele modli się i śpiewa trzymając w ręku książeczkę, a także wykładał katechizm Lutra. Hans otrzymał od Anioła nakaz, który miał przekazać ludziom, wzywając ich do pokuty, dobrego i sprawiedliwego życia, jako warunku nadejścia pokoju. Anioł nakazał też, by zwrócić się do władz, by otworzono Kościół i było w nim głoszone Słowo Boże. Opowieść ta wyraźnie wskazuje, iż otwarcie kościoła było wynikiem interwencji Boskiej.

${ }^{11}$ Wojna trzydziestoletnia spustoszyła wieś. Rozumiczan obecność wojsk szwedzkich i cesarskich kosztowała 16000 talarów.

12 B. Tranda, Johann Hermann, w: Encyklopedia Katolicka, t. 6, Lublin 1993, kol. 617.

${ }_{13}$ Por. K. Maler, Dzieje Głubczyc do roku 1742, Instytut Śląski, Opole 2003, s. 171-173.

${ }_{14}$ Ówczesne prawo dawało znaczne uprawnienia w kwestii życia religijnego właścicielom ziemskim. Zapewniało je prawo patronatu. Patronem kościoła zostawał ten, kto ofiarował ziemię pod budowę kościoła lub sam go wznosił. Zostać nim mógł też ten, kto utrzymywał duchownego lub odprawianie nabożeństw. Patron, obok praw honorowych, miał prawo do przedstawienia biskupowi swego kandydata na proboszcza. Patronat otwierał możliwość wprowadzania reformacji tam, gdzie chciał tego właściciel danego terytorium (M. Undas, Powstanie i rozwój Kościoła Ewangelickiego 
przez władzę w Krnovie. Poza obciążeniami finansowymi zażądano też wystawienia dwóch krzyży, jednego przy drodze do Oldřišova a drugiego przy murze kościelnym. Ponadto nakazano utrzymanie zapalonej lampy przez dzień i noc w kościele.

Ojcowie Jezuici wszelkimi sposobami starali się zmusić luteran do zmiany wyznania. Zabroniono im czytania ksiąg religijnych, które konfiskowano, modlitw i śpiewów w domach, małżeństwa wyjątkowo zawierano po wniesieniu bardzo wysokich opłat, grzebania zmarłych na przykościelnym cmentarzu, gdy ktoś pochował zmarłego w pobliżu domu, zmuszano do wykopania zwłok i zakopania w przydrożnym rowie. Za udawanie się do kościołów ewangelickich na nabożeństwa groziły kary pieniężne, konfiskata dóbr a nawet kara śmierci. Mimo to rozumicznie udawali się na nabożeństwa do Lewina Brzeskiego, gdzie w kościele ewangelickim jeszcze do rozpoczęcia I wojny światowej znajdował się chór oznaczony jako Rösnitzer Chor.

Właścicielka dóbr rozumickich Kunegunda von Bayern usiłowała wszelkimi sposobami ulżyć doli rozumiczan m.in. przez oddanie kościoła w administrację księdza z Třebomia, jednak jezuici nie ustawali w walce o dusze rozumiczan. Ulegli oni jednak po 22 latach, gdy ich misja załamała się w 1697 roku. Jedenastu jezuitom udało się pozyskać zaledwie dwie osoby. Po śmierci ostatniego Piasta ustała też możliwość uczęszczania rozumiczan na nabożeństwa w Księstwie Brzeskim. Dopiero wkroczenie w 1706 roku wojsk szwedzkich na Śląsk obudziło nadzieje ewangelików. W Altranstäd cesarz Józef I zgodził się na wybudowanie sześciu kościołów łaski, wśród nich kościoła w Cieszynie, który stał się dla rozumiczan nie tylko miejscem, do którego udawali się na nabożeństwa, ale skąd sprowadzali też potajemnie ewangelickich duchownych, którzy w ustronnych miejscach odprawiali nabożeństwa dla luteran. W wypadku Rozumic wyjątkowym miejscem jest Kanzel - ambona w lesie, usytuowana $\mathrm{w}$ jednym $\mathrm{z}$ głębokich wąwozów, upamiętniająca nabożeństwa w ukryciu. Podczas nich mogli wysłucha kazań i przyjąć Ostatnią Wieczerzę pod dwiema postaciami. Kanzel to usypane wzniesienie, na którym stawał duchowny podczas głoszenia kazań. Takich miejsc jest na Śląsku wiele ${ }^{15}$ i doczekały się one różnych form upamiętnienia. W Rozumicach ciągle tego nie uczyniono mimo zachęt. Kanzel jest natomiast świadectwem wyjątkowej wierności wyznawców luteranizmu swojemu duchowemu dziedzictwu, wytrwałego dążenia do umocnienia ducha Słowem Bożym i Ciałem oraz Krwią Chrystusa. To było powodem udawania się na nabożeństwa, mimo surowego zakazu i grożących za jego złamanie sankcji, do odległych miejscowości - Lewina Brzeskiego i Cieszyna.

Z Cieszynem związane jest też ruch pietystyczny, który silnie oddziaływał tu z Halle. Pietyzm był ruchem przebudzenia religijnego, który był reakcją na racjona-

\footnotetext{
na terenach dawnego Mniejszego Państwa Stanowego Wodzisław w latach 1517-1914, Warszawa 2014, s. 13-15; praca doktorska, wydruk komputerowy, w archiwum autora).

${ }^{15}$ Leśne kościoły. Miejsca tajnych nabożeństw ewangelickich w Beskidzie Śląskim, Wyd. Augustana, Bielsko-Biała 2009.
} 
listyczną ortodoksję luterańską, która przedkładała formalizm nad duchowe życie wspólnoty. Pietyści zmierzali do odnowy religijnej przez powszednie czyste życie chrześcijańskie. Philip Jacob Spenner (1635-1705), jeden z najbardziej znanych pietystów, teolog luterański zgromadzenia nabożne, tzw. collegia pietatis, poświęcał prostemu i praktycznemu wykładowi Pisma Świętego, wspólnym modlitwom i rozmowom religijnym. W Pia desideria (1675) propagował głoszenie Słowa Bożego nie tylko w kościele, ale także w rodzinie i na zebraniach poza świątynią. Twierdził, że powszechne kapłaństwo wymaga przestrzegania czystości życia osobistego przez członków zboru, praktykowania zasad religijnych, wiary wyrażającej się w miłości. Niewierzących i mylących się należy pozyskać modlitwą, dobrym przykładem i odpowiednim przedstawieniem spraw. Kazania powinny wzmocnić wiarę, budzić sumienia, rozwijać wewnętrznie. Spener kontynuował rozpoczętą przez reformację odnowę życia chrześcijańskiego. Cieszyn był pod dużym wpływem innego pietysty Augusta Hermanna Franckego (1663-1727), będącego w bliskich kontaktach ze Spenerem. Działalność Franckego w Halle porównywana jest do ożywienia, jakie spowodował Luter w Wittenberdze. W Halle Francke założył szkołę dla ubogich i dom sierot, z czasem powstał kompleks budynków z apteką, księgarnią, drukarnią i biblioteką, zwany zakładem Franckego ${ }^{16}$. Ożywiona działalność ośrodka w Halle z Franckem na czele przypada na okres rozkwitu i silnego oddziaływania pietystów na inne obszary. Duchowe początki kościoła Jezusowego w Cieszynie i szkoła, która przy nim powstała, związane są z halleńskim pietyzmem. Francke uważał za pilną sprawę upowszechnienie Ewangelii, także na terenach habsburskich objętych rekatolizacją. W tym celu nawiązał osobiste kontakty z hrabią Erdmannem von Promnitz w Pszczynie, z Wenzlem Ludwigiem Hencklem von Donnersmarckiem Boguminie ${ }^{17}$ i jego bratem Heinrichem Erdmanem z Turyngii. W roku 1698 zamierzał w Halle utworzyć specjalny oddział dla dzieci śląskiej szlachty. W sytuacji, w jakiej znalazł się cesarz po zawarciu konwencji w Altranstädt, dostrzegł Francke możliwość udzielenia wsparcia śląskim protestantom. Cieszyn miał być centrum promieniującym na społeczności wschodnie i południowe ${ }^{18}$. Pietyści mieli wielu zwolenników na Śląsku austriackim. Warunki pracy pierwszych ewangelickich duchownych były

${ }^{16}$ M. Kotsch, August Hermann Francke. Pädagoge und Reformer, Christliche Verlagsgesselschaft, Dillenburg 2010; A. Buzek, Historia Kościoła, Warszawa 1957.

${ }_{17}$ Obok Promnitza i Donnersmarcka, Julius Gottlieb hrabia Sunnegh z Bielska tworzył grono „trzech grafów”, jak określano tych protestanckich arystokratów śląskich, wspierających finansowo budowę kościoła łaski w Cieszynie, będącego centrum pietyzmu górnośląskiego. Zob. J. Polak, „Pierwszy Fundator” Kościoła Jezusowego Erdmann II von Promnitz (1683-1745, „Pamiętnik Cieszyński, 2016, t. 21, s. 48.

${ }^{18}$ L. Petry, Dem Osten zugewandt. Gesammelte Aufsätze zur schlesischen und ostdeutsche Geschichte, Sigmarinien 1983; H. Patzelt, Pietyzm na Śląsku Cieszyńskim. Referat wygłoszony podczas Spotkania Ewangelików Czterech Narodów w Czeskim Cieszynie, dnia 25 września 1999 r., „Gazeta Ewangelicka” 2000, nr 3; wersja elektroniczna: www.luteranie.pl/biblioteka/dkosciol/te/ patzelt1.htm (dostęp: 11.11.2006); zob. też tenże, Pietyzm na Śląsku Cieszyńskim, http://old.luteranie. $\mathrm{pl} / \mathrm{pl} /$ ?D=387 (dostęp: 27.08.2013). 
trudne. Co prawda liczni wierni słuchali ich kazań głoszonych w języku polskim i niemieckim a dzieci uczęszczały do szkoły, jednak działalność utrudniała im bieda i problemy, jakie stwarzali jezuici i dominikanie, oskarżając luteran o kacerstwo i zabraniając ludności kontaktowania się z ,emisariuszami diabła”. W 1710 roku Voigt, Schneider, Plattani i Jokisch musieli opuścić Śląsk, gdyż na mocy recesu egzekucyjnego duchownymi na Śląsku mogli być tu tylko urodzeni. Pojawili się więc luterańscy duchowni ze Śląska, a także nauczyciele z Węgier i Siedmiogrodu. To z ich działalnością zapewne należy wiązać informację, iż rozumiczanie sprowadzali duchownych $z$ Węgier do odprawienia tajnych nabożeństw ${ }^{19}$. Z czasem jednak w Cieszynie przyjęto porządek szkolny z Halle, a najwyższym pastorem został pietysta Johann Adam Steinmetz. Rozumiał on misyjny charakter swojego urzędu, a za zadanie cieszyńskiego kościoła łaski uznał objęcie opieką utajonych protestantów we wschodnich Morawach i Górnych Węgrzech, gdzie wolność wyznania ponownie ograniczono w latach 1714-1715. Steinmetz pozyskał dla kościoła w Cieszynie pastorów władających językiem polskim i czeskim. Zadaniem misjonarzy było jednoczenie luterańskich Słowian zamieszkałych na habsburskich ziemiach dziedzicznych we współpracy z czeskimi wygnańcami i słowackimi pietystami. Przebudzenie duchowe, promieniujące z Halle, objęło dużą część szlachty, mieszczaństwa i chłopów w odległych zakątkach parafii kościoła łaski i sięgało po wschodnie Morawy i Górne Węgry $^{20}$. Ten pietystyczny ruch objął bez wątpienia luteran z Rozumic. Silna ich więź z kościołem w Cieszynie została potwierdzona uczestnictwem w obchodach jubileuszu wręczenia Konfesji Augsburskiej (Confessio Augustana) w 1730 roku, który uczczono pieśnią złożoną z czternastu zwrotek. W zachowanym jej zapisie w nagłówku czytamy: Das von Gott in Gnaden heimgesuchten Rösnitz wollte bey der in der Evangelischen Gnadenkirche von Teschen angestellten Jubel Feyer 1730. Zur schuldigen Dankbarkeit aufmuntern Johan Kromer, Buchbinder ${ }^{21}$. Pieśń ta opisuje doświadczenia mieszkańców Rozumic od momentu przyjęcia luteranizmu. Wyakcentowuje przede wszystkim ożywczą moc Słowa Bożego, co jest charakterystyczną

${ }^{19}$ M. Fiebig, dz. cyt., s. 28.

${ }^{20}$ O. Wagner, Mutter Kirche vieler Länder. Geschichte der evangelischen Kirche im Herzogtum Teschen 1545-1918-20, Wien-Köln-Graz 1978, s. 67-79. Toż w języku polskim: Kościół macierzysty wielu krajów. Historia Kościoła Ewangelickiego w Księstwie Cieszyńskim w latach 1545-1918/20, Cieszyn-Bielsko-Biała 2008.

${ }^{21}$ G. Kremser, Raptularz, 1784, rkps. Jest to rękopiśmienny, niepaginowany tom z nieczytelną kartą tytułową, został on sporządzony przez Gottfrieda Kremsera na przełomie XVIII i XIX stulecia. Stanowi zaledwie fragment wielotomowego raptularza domowego. Ten tom raptularza jest w posiadaniu Giseli Kremser w Neundorf pod Dreznem; [cyfrowa kopia w posiadaniu autora tego artykułu]. Na podstawie zapisu tej pieśni w raptularzu wiemy, iż miejscowa tradycja przyjmowała rok 1524, jako rok wprowadzenia pierwszego ewangelickiego kaznodziei. W przypisie do wiersza 16 w pierwszej strofy, czytamy: „1524 ist der Erste Evangelischer Prediger in Rößnitz eingeführt wordem”. Niepełna wersja pieśni została też podana przez pastora Fiebiga (dz. cyt., s. 27-28), nie wszystkie wersy pastor cytował, pominął m.in. wzmiankę o cudownym zdarzeniu z Hansem Laske, które miejscowa tradycją przyjmowała za w pełni wiarygodne. 
cechą ruchów reformatorskich. Treść tej pieśni wyraża niezachwianą wiarę w moc wiernego Boga, który pomaga wiernym, naśladującym Jezusa w miłości i cierpieniu.

Głównym promotorem pietyzmu był hrabia Ludvik von Zinzendorf, który utworzył w Herrnhut osadę dla prześladowanych w cesarstwie habsburskim braci morawskich. Posiadał on zwolenników wśród szlachty górnośląskiej. W 1726 roku w sierpniu hrabia Zinzendorf udał się w sprawie morawskich emigrantów do barona Schrattenbacha w towarzystwie Immanuela Traugotta Jerichoviusa. Odwiedził „przebudzonych”, jak nazywano zwolenników pietystów, Ernsta Juliusa von Seidliz i księcia Johanna Adama Steinmetza w Cieszynie. W czasie tej podróży hrabia Zinzendorf przybył też do Rozumic (był też w Sudicach i Ściborzycach Wielkich) ${ }^{22}$, gdzie znajdowało się centrum pietystycznego kręgu, do którego należeli „przebudzeni” z okolicznych miejscowości.

Upowszechnienie się pietyzmu wśród mieszkańców Rozumic, stało się przyczyną kryzysu, który tu miał miejsce już po uzyskaniu wolności religijnej, gdy duża część Górnego Śląska znalazła się w Królestwie Pruskim po zajęciu przez Fryderyka Wielkiego Śląska w 1742 roku. Wspólnota luterańska w Rozumicach przystąpiła do budowy domu modlitwy, gdyż kościół nadal był zamknięty, po otrzymaniu 26 lutego 1743 roku zgody na jego budowę. 21 lipca tegoż roku nastąpiła też wokacja pierwszego kaznodziei, którym był rektor z Cieszyna, późniejszy radca konsystorialny i superintendent, Johann Ernst Gotlieb von Radetzky. Wybór ten był wynikiem silnych więzi łączących rozumiczan z Cieszynem. W połowie 1743 roku próbę założenia kolonii w Rozumicach podjęła wspólnota braci morawskich z Herrnhut, którzy mieli tu wielu zwolenników zarówno w samych Rozumicach, jak i w sąsiednich Ściborzycach Wielkich (morawskojęzyczna społeczność luterańska istniała tutaj o równie długiej historii, jak w Rozumicach), posiadając zgodę na budowę domu modlitwy. Rozpoczął się wówczas spór przerwany II wojną śląską, po której herrnhuterzy kontynuowali budowę domu modlitwy w 1746 roku doprowadzając ją niemal do końca. W 1749 roku decyzja króla zakazano herrnhuterom tworzenia kolonii w Rozumicach, wyjaśniając, że nie było zamiarem królewskim zezwolenie na działalność prozelicką, a tym bardziej na budowanie nowego kościoła obok już istniejącego. Wprawdzie kaznodzieja braci morawskich w Rozumicach, Johann Michael Lauterbach próbował się jeszcze odwołać od tej decyzji, jednak skutek był taki, że zakazano herrnhuterom prozelityzmu. Ostatecznie sprawę zakończyła komisja, przed którą 26 stycznia 1751 roku stawili się ich zwolennicy ze Ściborzyc Wielkich i Rozumic. W wyniku działań komisji większość herrnhuterów powróciła do Kościoła ewangelickiego, a nieliczni opuścili Rozumice, a później znaleźli się w Pawłowiczkach, gdzie powstała herrnhuterska kolonia w 1780 roku²3.

${ }^{22}$ M. Fiebig, dz. cyt., s. 31.

${ }^{23}$ R. Hofrichter, Heimatkunde des Kreises Leobschütz, Tl. II: Geschichtliches, H. III: Geschichtliches der einzelnen Ortschaften des Kreises Leobschütz mit 111 Abbildungen und Plänen, Leobschütz 1914, s. 560 [przedruk: Verlag Ute Kiedrof, Remscheid 1982]. Zob. też H. Karczyńska, 
Budowę domu modlitwy, społeczność Rozumic w 1750 roku miała na tyle zaawansowaną, by można w nim było odprawić nabożeństwa. Zakupiono także mały dzwon, który już po wybudowaniu nowego kościoła sprzedano w 1819 roku do sąsiednie wsi Hněvošice (wówczas Schreibersdorf) ${ }^{24}$, dziś w miejscowość w Republice Czeskiej. Wojny śląskie były na tyle dotkliwe dla mieszkańców Rozumic i Ściborzyc Wielkich, iż społeczności te nie były w stanie w pełni sfinansować budowy domu modlitwy. Jeszcze w 1778 miała miejsce kolekta w prowincji śląskiej, która wsparła tę budowę.

Powstanie domu modlitwy nie przyniosło regularnego i spokojnego życia ewangelickim społecznościom Rozumic i Ściborzyc Wielkich, które wówczas tworzyły jedną parafię, do której należało wiele ewangelickich wspólnot w okolicy. W roku 1791 urząd biskupi w Ołomuńcu postanowił stary kościół parafialny, plebanię wraz zabudowaniami i katolicką szkołę zbudować na nowo. W międzyczasie nie tak dawno wzniesiony dom modlitwy był już w stanie, który groził zawaleniem, bo był źle zbudowany. Rok wcześniej ewangelicka społeczność Rozumic zwróciła się do arcybiskupstwa w Ołomuńcu z prośbą, by kościół parafialny mógł służyć tzw. symultanicznym nabożeństwom, a w zamian gmina chciała partycypować w kosztach remontu kościoła. Odpowiedź była odmowna, stąd zbór w Rozumicach skierował sprawę do najwyższego królewskiego urzędu w Berlinie, a ten przekazał ją pismem z 22 lutego 1792 roku urzędowi w Brzegu (Ober Amts Regierung). Urząd ten zalecił przychylne ustosunkowanie się do prośby zboru, jednak arcybiskupstwo sprzeciwiło się temu. Podjęto działania ze strony Kościoła katolickiego, które łamały obowiązujące prawo, co doprowadziło do procesu sądowego, który zakończył się bezprecedensowym wyrokiem z 27 czerwca 1800 roku. 13 lipca 1800 roku deputowani z Rozumic powrócili z Brzegu z wieścią, że gmina wygrała proces, co oznaczało przywrócenie ewangelickiej administracji kościelnej. Po stu siedemdziesięciu dwóch latach (kościół odebrano luteranom po raz pierwszy w 1628 roku), pełnych bolesnych i tragicznych wydarzeń, kościół stał się formalnie własnością ewangelików. Jego stan nie pozwalał na remont, dlatego go rozebrano. 7 września 1804 roku położono kamień węgielny pod nowy budynek. Nowy kościół poświęcono uroczyście 18 października 1807 roku. Do ewangelickiej parafii Rozumice włączono luteran z następujących miejscowości: Sudice (Zauditz) z dwudziestoma ewangelickimi posesjami, Dzierżysław (Dirschel) - pięćdziesięcioma dwoma, Rogożany (Rosen) - ośmioma, Branice (Branitz) - sto sześćdziesiąt osób. Ewangelicy pojedynczo zamieszkujący w przygranicznych wsiach przybywali tu na nabożeństwa. Z początkiem XIX stulecia do komunii przystępowało 1000 osób. Do ewangelickiej parafii Rozumice w chwili położenia kamienia węgielnego należało 1500 osób. Wszystkie okoliczne wsie były katolickie, jedynie Rozumice od czasów reformacji były całkowicie luterańskie, podobnie jak Ściborzyce Wielkie z sześcioma katolickimi posesjami. Liturgiczne nabożeństwa

Odnowiona Jednota Braterska w XVIII-XX wieku. Z dziejów ruchu religijnego herrnhutów w krajach Europy Środkowo-Wschodniej i na świecie, Warszawa 2012, s. 228.

${ }^{24}$ M. Fiebig, dz. cyt., s. 35. 
i kazania odbywały się tu w języku niemieckim i czeskim, gdyż okoliczne wsie były niemiecko- i czeskojęzyczne ${ }^{25}$. Do niemieckojęzycznych należały m.in.: Kietrz (Katscher), Pilszcz (Piltsch), Rozumice (Rösnitz), Ludmierzyce (Leimerwitz), Sudice (Zauditz), Třebom (Thröm), a do czeskojęzycznych: Ściborzyce Wielkie (Steuberwitz), Hněvošice (Schreibersdorf), Kobeřice (Köberwitz), Oldřišov (Odersch), Sluyovice (Schlauswitz), Nasiedle (Nassiedel), Branice (Branitz), Lubotń (Liptin) ${ }^{26}$. W pierwszych dziesięcioleciach XIX wieku kościół w Rozumicach obejmował duszpasterską opieką ewangelików na zachodzie po Branice, na południowym zachodzie po Hulczyn (niem. Hultschin, cz. Hulčin), na północy po Baborów (Bauerwitz), na południu po Opawę (Troppau). Dzialalność ewangelickiego centrum jakim były Rozumice w nowych warunkach tolerancji religijnej w Prusach przyniosła szybko owoce. Pastor z Rozumic prowadził pogrzeby w Opawie. W latach siedemdziesiątych XIX wieku zbudowano na jej terenie dwa nowe kościoły - w Ściborzycach Wielkich (poświęcenie miało miejsce w 1873 r., zbór liczył 800 osób), w Kietrzu (w 1875 r., z udziałem braci herrnhuterów z Pawłowiczek) ${ }^{27}$. Z czasem własne kościoły zbudowały inne społeczności należące do parafii Rozumice. Według spisu z 1905 roku parafia Rozumice liczyła trzy tysiące osób (wśród czterdziestu jeden tysięcy katolików), dzieliła się na dwadzieścia cztery zbory i pięć okręgów w powiecie głubczyckim i 18 zborów i 15 okręgów w powiecie raciborskim. Na tej podstawie można powiedzieć, iż luteranie tej społeczności stali się źródłem odnowy ewangelickiej w tej części Górnego Śląska.

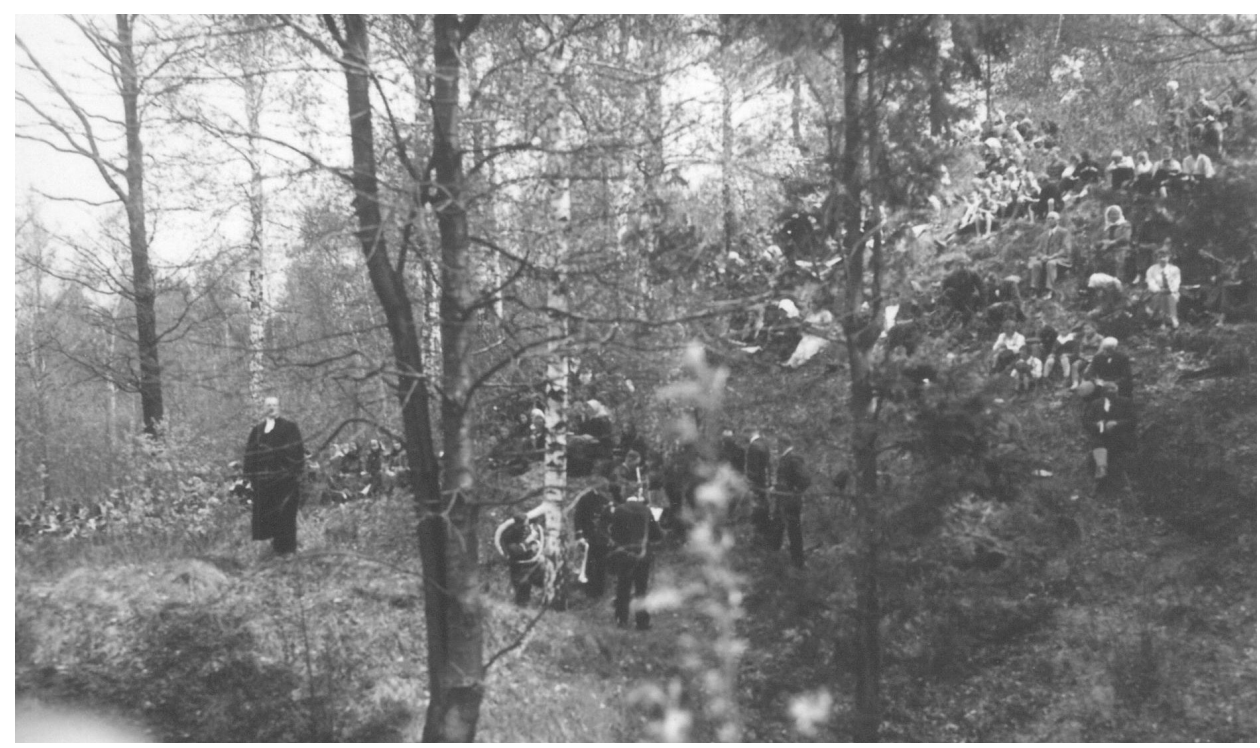

Fot. Nabożeństwo na leśnej ambonie stoi pastor Arnold Hitzer

${ }^{25}$ W Ściborzycach Wielkich i w Branicach na co dzień używano dialektu morawskiego.

${ }^{26}$ M. Fiebig, dz. cyt., s. 54, 55.

${ }^{27}$ R. Hofrichter, dz. cyt., s. 435. 


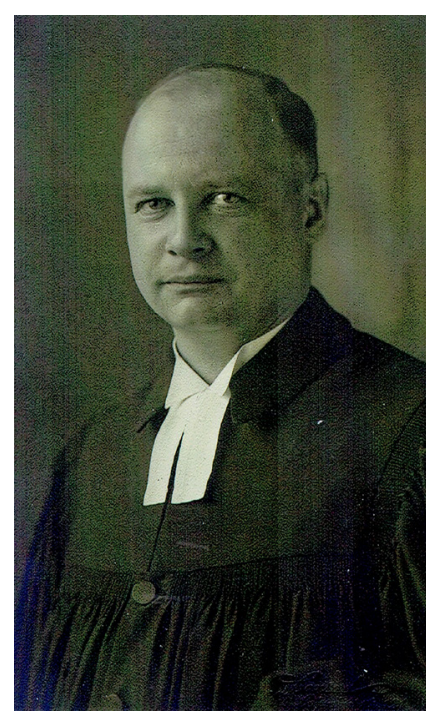

Fot. Arnold Hitzer jesień 1938

$\mathrm{Z}$ braku miejsca zmuszeni jesteśmy pominąć wiele interesujących wątków z historii tej społeczności. Na zakończenie chcemy zwrócić uwagę na jedną postać, która zarazem dopełni polifoniczność tej luterańskiej historii. O czym zatem jeszcze opowiada nam to miejsce pamięci? Szczególną postacią związaną z ewangelicką historią Rozumic jest pastor Arnold Hitzer ${ }^{28}$, który urzędował tu od 1930 do 1937 roku. Ten duchowny uważał, że zbór w Rozumicach jest szczególnie przywiązany do nauk Marcina Luta. Znajdująca się w miejscowym lasku ambona - służąca $\mathrm{w}$ czasach prześladowań luteran jako miejsce potajemnych nabożeństw - w czasach księdza Hitzera była miejscem uroczystości, które odbywały się w święto Wniebowstąpienia, w dzień dorocznych misji dla dużego okręgu ewangelickiego. W czasach nazizmu było to miejsce symboliczne dla podtrzymania historycznej świadomości miejscowych chrześcijan, wobec zagrożenia ze strony totalitarnego systemu dla religii. W momencie dojścia do władzy Hitlera do władzy usiłowano z pastora uczynić bezwolnego pomocnika nowego reżimu. Wobec dążeń nazistów w Kościele ewangelickim Niemiec ukształtowała się opozycja wobec działań władzy, znana jako Bekennende Kirche - Kościół wyznający. Pewnej niedzieli pastor miał zamiar odczytać wezwanie do młodzieży wydane przez Kościół wyznający, ale w nocy został aresztowany i przewieziony do więzienia w Opolu. Zwolniono go po trzech dniach. Jednak wkrótce został zatrzymany przez tajną policję i przekazano mu nakaz opuszczenia Śląska. Aresztowano go 17 grudnia 1937 roku. W ciągu sześciu miesięcy sześciokrotnie zmieniano miejsce jego uwięzienia. Zachowały się karteczki, które przekazywał żonie podczas wizyt $\mathrm{w}$ więzieniu, były na nich teksty pieśni. $\mathrm{W}$ jednym $\mathrm{z}$ miejsc odosobnienia, gdzie miał więcej wolności, gdyż strażnik otwierał cele i pastor mógł czytać wraz z trzema innymi więźniami - komunistami Ewangelię Łukasza z dostarczonych przez żonę pastora katolickich przekładów Nowego Testamentu. Gdy pastora Hitzera przeniesiono do zakładu karnego w Raciborzu, wytoczono mu proces z zamiarem osadzenia go w obozie koncentracyjnym. Jednak zeznania starszych kościoła w Rozumicach złagodziły wyrok. Skazano go na ciężkie więzienie i wydalenie ze Śląska. Arnold Hitzer opuścił Śląsk w 1942 roku $^{29}$. Żona pastora Hitzera jeszcze trzy lata mieszkała w Rozumicach, wspierając wikarych

${ }^{28}$ Hitzer podobnie jak Dietrich Bonhoeffer reprezentował Bekennde Kirche (Kościół wyznający). Polemizował z Bonhoefferen w kwestiach teologicznych.

${ }^{29}$ G. Ehrenforth, Die schlesische Kirche im Kirchenkampf 1932-1945, Göttingen 1968, s. 256. 
i diakonów Kościoła wyznającego. Pastor trafił do Prus Wschodnich, a żona dołączyła do niego wraz z dziećmi.

Na zakończenie, autor pragnie krótko zaprezentować o czym opowiada miejsce pamięci jakim jest ruina ewangelicki kościół w Rozumiczch, a także czym jest wskazana polifoniczność i co łączy w jedność różne nurty ewangelickiego Kościoła, z jakimi mieliśmy do czynienia śledząc dzieje społeczności Rozumic. Od samego początku religijne życie tej społeczności wiąże się ruchami przedreformacyjnymi, których oddziaływanie z Moraw głównie widoczne było na Śląsku. Miejscowa tradycja akcentuje przede wszystkim kontakty z braćmi morawskimi w Opawie. Społeczność ta ukształtowała się po śmierci Jana Husa i musiała działać w ukryciu, przez co niewątpliwie silniej rozwijała się w niej osobista pobożność oparta na czytaniu Słowa Bożego. Oddziaływanie to było na tyle silne, że rozumiaczanie po objęciu Księstwa Karniowakiego przez Georga Hohenzollerna, wkrótce uznali luteranizm jako swoje wyznanie i pozostali mu wierni, jako cała społeczność do końca, czyli do 1946 roku, kiedy ich wypędzono tym razem już z Polski.

Prześladowania, które dotknęły ich, podobnie jak inne społeczności ewangelickie nie odwiodły ich od swojego Kościoła, więcej są rzadkim przykładem na Górnym Śląsku wytrwania całej społeczności w swoim luterańskim wyznaniu. Społeczność ta stanęła przed trudnym problemem, jaki pojawił się w połowie XVIII stulecia - podziału zboru na wyznawców luteran i herrnhuterów, przy jednoczesnym silnym oddziaływaniu ruchu pietystycznego. Ruch

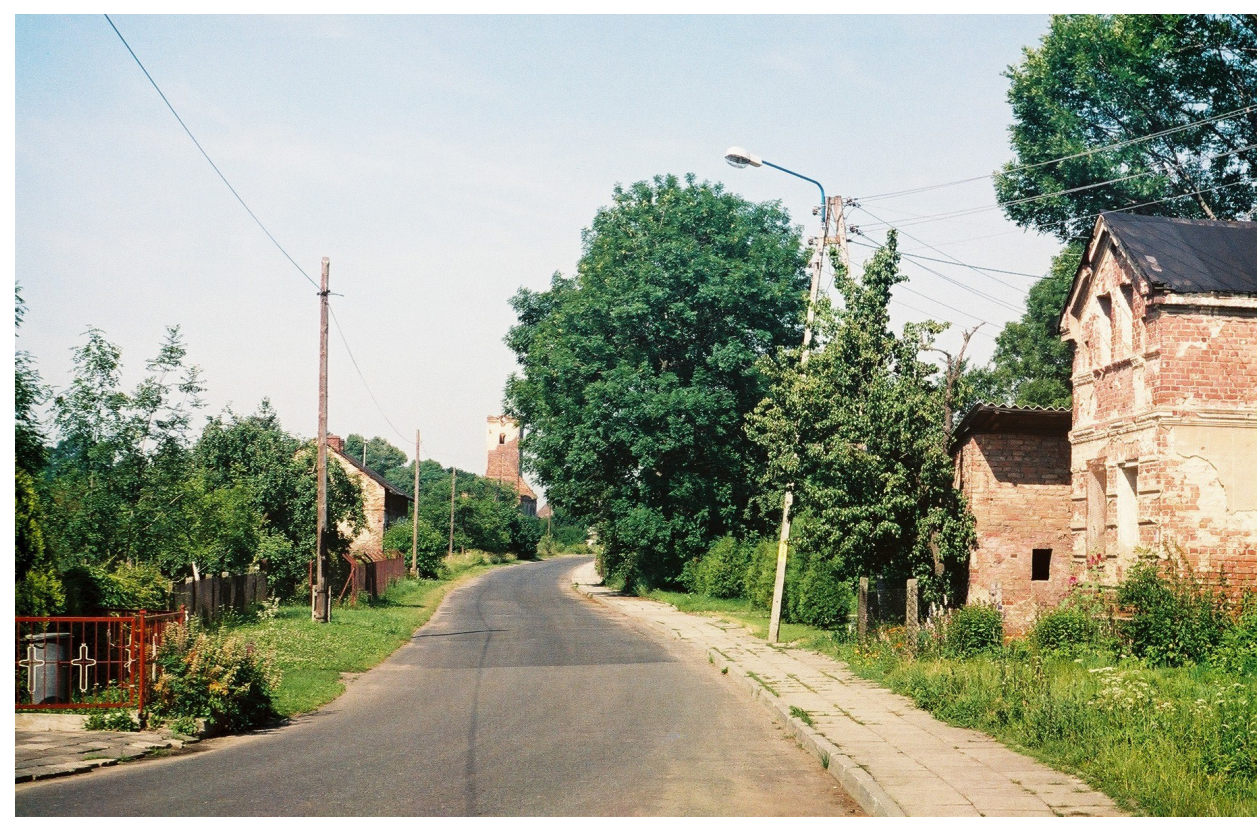

Fot. Rozumice w głębi ruina kościoła ewangelickiego - 2005 


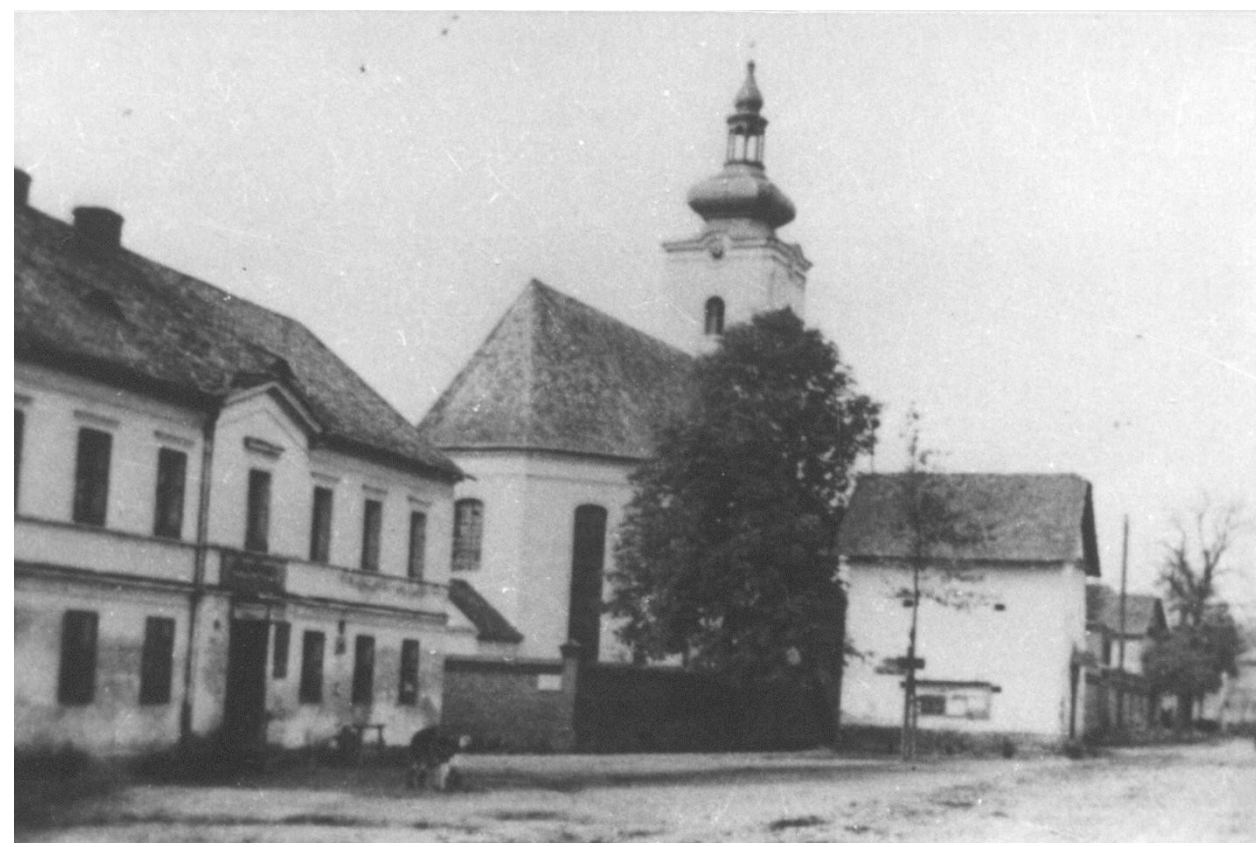

Fot. Kościół ewangelicki w Rozumicach, fot. ze zbiorów Elsbeth Wehowsky

pobożnościowe zarówno przedreformacyjne (bracia morawscy), jak i poreformacyjne (pietyści) ${ }^{30}$ kształtowały pobożność indywidualną silnie związaną z czytaniem Biblii i osobistym życiem duchowym. Ruina Kościoła w Rozumicach jest też miejscem pamięci odsyłającym do czasu potwornego totalitaryzmu, który z całą bezwzględnością walczył z autentyczną religijnością, gdyż ta obnażała jego kłamstwo w dążeniu do zniszczenia Kościoła. W tych czasach szalejącej nienawiści symbol jakim była ambona (Kanzel), przy której odbywały się w ukryciu przed władzą nabożeństwa, oddziaływał na religijną świadomość okolicznych ewangelików.

Przedstawiona tu rekonstrukcja różnorodności duchowości ewangelickiej ukazuje tylko główne nurty, aby zaakcentować potrzebę szczegółowych badan, które odsłaniają przebogaty świat ludzkich doświadczeń, jaki kryje historia miejsc,

${ }^{30}$ W końcu osiemnastego stulecia (1799) Georg Grittner z Rozumic zakupił tom zatytułowany Vier Bücher vom wahren Chritentum [Cztery księgi o prawdziwym chrześcijaństwie] Johannesa Arndta, wydaną w Lüneburgu w 1679 roku, co świadczy o tym, iż duch pietyzmu utrzymywał się długo w Rozumicach. W odręcznej notatce na stronie przedtytułowej Vier Bücher vom wahren Chritentum Georg Gritner odręcznie napisał: George Grittner dieses Buch hab. ich Gekauft von 3 Fl. und 10 fgl. Den 28th December, Anno 1799. Niemand kann den Trost ergründen der in diesem Buch zu finden. So ihr mich von ganzem Herzen suchen werdet so will ich mich von euch finden lassen spricht der Herr. Jeremia 29 vers 13.14.

${ }^{{ }^{C}}$ Ztery księgi J. Arndta obok jego Ogródka rajskiego należały do ulubionych lektur pobożnych protestantów. Cztery księgi wydano także w wersji dla katolików. Spener, zwany ojcem pietystów, szedł drogą Arndta. Wśród pietystów Arndt miał zawsze swoich wielbicieli. 


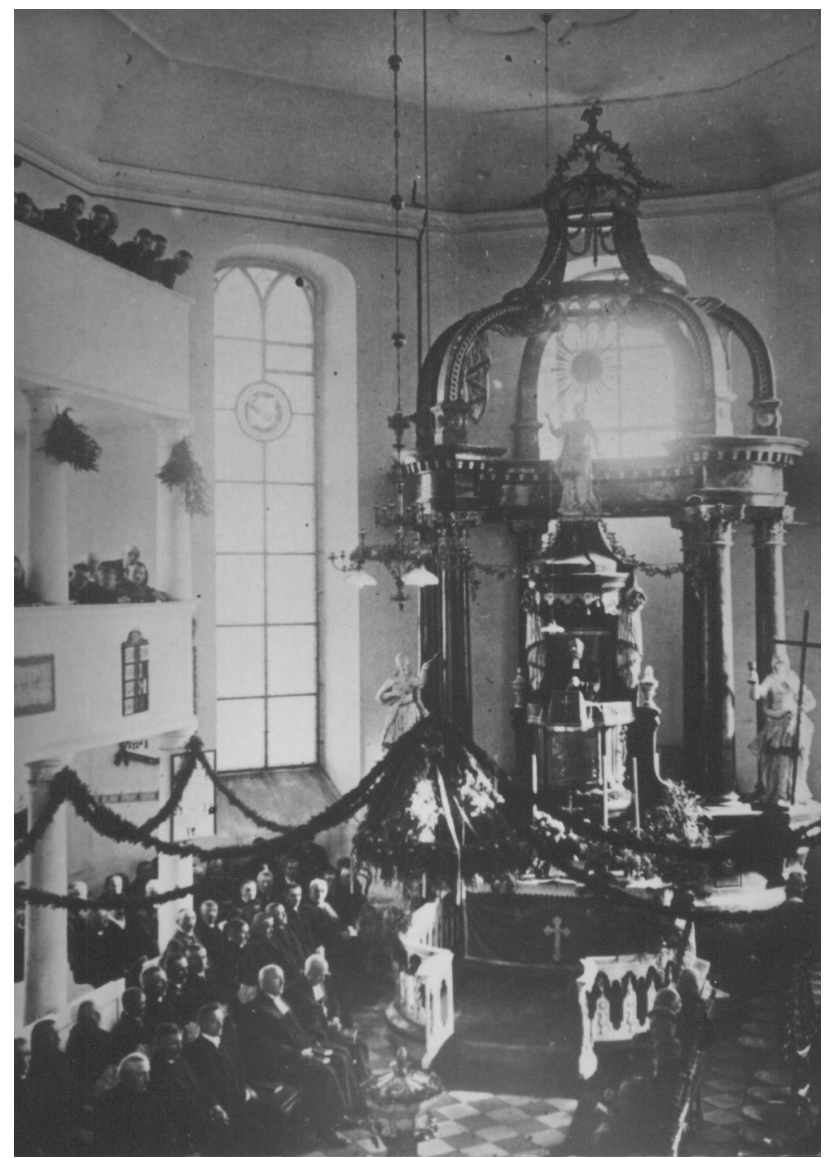

Fot. Wnętrze kościoła ewangelickiego w Rozumicach, na ambonie pastor arnaold Hitzer

którymi zainteresowanie od czasu przełomu politycznego w Polsce i w Europie Środkowo-Wschodniej przeżywa swój ogromny rozkwit.

Ruina kościoła w Rozumicah jest w historii Górnego Śląska świadectwem wyjątkowej wierności chrześcijańskiej tradycji całej wspólnoty miejscowej. Dziś zdumiewa wyjątkowy brak działań władz miejscowych, zwłaszcza gminnych dla upamiętnienia tej niezwykłej społeczności. Zdumiewa zwłaszcza dlatego, że dziś gdy na dziedzictwo kulturowe Unia Europejska przeznacza określone fundusze, uboga gmina nie chce wykorzystać tej możliwości, mimo wielokrotnych zachęt i podejmowanych w tym kierunku działań przez ludzi dobrej woli. Władze gminy nie podjęły działań w celu wpisania obiektu na listę zabytków, obawiając się wynikających stąd zobowiązań do zabezpieczenia obiektu. Straciły jednak znacznie więcej, jeśli nie same władze - to niewątpliwie miejscowe społeczeństwo pozbawiono kilku miejsc pracy, a także możliwość uatrakcyjnienia edukacji i rozwoju turystyki. 


\section{BIBLIOGRAFIA}

Anders F. G. E., Statistik der Evangelischen Kirche in Schlesien nebst eine Kirchen-Carte, Wilhelm Gottlieb Korn, Breslau 1848.

„Bausteine für den Aufbau Zions. Monatsschrift für evangelische Gemeinden” 1864 (Dezember), s. 94 [Evangelisches Zentralarchiv in Berlin (ZA5071/12) Signatur: EZA 200/ 1 /4490, karta: D. $107 \mathrm{R}]$.

Buzek A., Historia Kościoła, Warszawa 1957.

Die Geschichte der evangelischen Kirche zu Rösnitz bei Troppau, „Fliegende Blätter für den Aufbau Zions in der Diaspora" 1863, Nr 1, s. 6 [Evangelisches Zentralarchiv in Berlin (ZA5071/12) Signatur: EZA 200/ 1 /4490, karta: D. 75 R].

Eberlein H., Schlesische Kirchengeschichte, Bd. I. Das Evangelische Schlesien, 3. Aufl., Verlag der Schlesischen Evangelischen Zentralstelle, Goslar 1952.

Ehrenforth G., Die schlesische Kirche im Kirchenkampf 1932-1945, Göttingen 1968.

Fiebig M., Geschichte der Ewangelischen Kirche zu Rösnitz (O.=S.) nebst Mitteilungen [ber Pfarrei, Schule und sonstige wichtige Vorgänge allgemeinerer Art aus dem Leben der Heimat. Zur Feier des hundertjährigen Kirchenweihjubiläums am 18 October 1907 der jubilierenden Gemeinde gewidmet von ihrem Pfarramt, Rösnitz 1907.

Gładkowski K., Kanzel/ambona. Protestancka wspólnota lokalna na Górnym Śląsku, Olsztyn 2008.

Hofrichter R., Heimatkunde des Kreises Leobschütz, Tl. II: Geschichtliches, H. III: Geschichtliches der einzelnen Ortschaften des Kreises Leobschütz mit 111 Abbildungen und Plänen, Leobschütz 1914 [przedruk: Verlag Ute Kiedrof, Remscheid 1982].

Karczyńska H., Odnowiona Jednota Braterska w XVIII-XX wieku. Z dziejów ruchu religijnego herrnhutów w krajach Europy Środkowo-Wschodniej i na świecie, Warszawa 2012.

Kotsch M., August Hermann Francke. Pädagoge und Reformer, Christliche Verlagsgesselschaft, Dillenburg 2010.

Kremser G., Raptularz, 1784, rkps.

Kreßel, Die Reformation in Ansbach, w: H. Sommer (hrsg.), Es geschah im Namen des Glaubens. Evangelisch in Dekanat Ansbach, Verlag der Ev.-Luth. Mission, Erlangen 1991, s. 15-19.

Leśne kościoły. Miejsca tajnych nabożeństw ewangelickich w Beskidzie Śląskim, Wyd. Augustana, Bielsko-Biała 2009.

Maler K. , Dzieje Głubczyc do roku 1742, Instytut Śląski, Opole 2003.

Nora Pierre, Mémoire collective, w: Faire de l'histoire, sous la dir. de J. Le Goff, P. Nora, Paris 1974. Patzelt H., Pietyzm na Ślasku Cieszyńskim. Referat wygłoszony podczas Spotkania Ewangelików Czterech Narodów w Czeskim Cieszynie, dnia 25 września 1999 r., „Gazeta Ewangelicka” 2000, nr 3; wersja elektroniczna: www.luteranie.pl/biblioteka/dkosciol/te/patzelt1.htm

Patzelt H., Pietyzm na Śląsu Cieszyńskim, http://old.luteranie.pl/pl/?D=387 (dostęp: 27.08.2013).

Petry N., Dem Osten zugewandt. Gesammelte Aufsätze zur schlesischen und ostdeutsche Geschichte, Sigmarinien 1983.

Polak J, „Pierwszy Fundator” Kościoła Jezusowego Erdmann II von Promnitz (1683-1745, „Pamiętnik Cieszyński, 2016, t. 21, s. 39-66.

Spener Ph. J., Pia desideria - Umkher in die Zukunft, Brunner Verlag, Gießen 1995.

Szpociński A., Miejsca pamięci (lieux de mémoire), „Teksty Drugie”, 2008, nr 4; wersja elektroniczna: www.ceeol.com.

Tranda B., Johann Hermann, w: Encyklopedia Katolicka, t. 6. Lublin 1993, kol. 617.

Undas M., Powstanie i rozwój Kościoła Ewangelickiego na terenach dawnego Mniejszego Państwa Stanowego Wodzisław w latach 1517-1914, Warszawa 2014 (praca doktorska, wydruk komputerowy). 
Wagner O., Mutter Kirche vieler Länder. Geschichte der evangelischen Kirche im Herzogtum Teschen 1545-1918-20, Wien-Köln-Graz 1978.

Wagner O., Kościót macierzysty wielu krajów. Historia Kościoła Ewangelickiego w Księstwie Cieszyńskim w latach 1545-1918/20. Cieszyn-Bielsko-Biała 2008.

\section{Streszczenie}

Autor prezentuje tu uszczegółowione wyniki swoich badań na religijną przeszłością luterańskiej społeczności z miejscowości Rösnitz (dzisiejsza polska nazwa Rozumice) na Górnym Śląsku. Wieś ta jest położona na granicy z dzisiejszą Republiką Czeską. Dziś jest to miejsce pamięci związane $\mathrm{z}$ ciągłością protestanckiej tradycji, wliczając w to ruchy przedreformacyjne, od XV wieku.

Ciągłość wyznania luterańskiego od 1523 roku społeczności, którą badania autora wykazały, przeczy generalizującej tezie, mówiącej o całkowitej rekatolizacji Górnego Śląska. W tym artykule wyeksponowano jeden z wątków historii tego miejsca pamięci - różnorodności protestanckiej tradycji, jaką ukazują badania przeszłości tej społeczności luterańskiej. Na tę różnorodną tradycję składają się przedreformacyjne ruchy chrześcijańskie, do których należą bracia morawscy, z którymi jeszcze przed końcem XV wieku nawiązali kontakt mieszkańcy Rösnitz. W wierzeniach tej społeczności pojawiają się też wątki charakterystyczne dla waldensów, znane na Śląsku. Ruchy te przygotowały społeczność rozumiczan na przyjęcie luteranizmu. W okresie kontrreformaji społeczność ta nie poddała się rekatolizacji. Później silnie oddziałuje tu ruch pietystyczny, sam hrabia Ludwik von Zinzendof odwiedza Rösnitz, gdzie przemawia do licznie tu zgromadzonych z okolicznych miejscowości przebudzonych. Dochodzi nawet do rozłamu w dotąd zjednoczonej gminie, którego skutkiem było wyemigrowanie zwolenników jednoty braterskiej do Herrnhut.

Słowa kluczowe: reformacja, luteranie, Górny Śląsk, husytyzm, bracia morawscy, pietyzm, Herrnhut

RÖSNITZ / ROZUMICE POLYPHONICITY OF THE UPPER SILESIAN PROTESTANT TRADITION

Sum mary

The author presents here the detailed results of his research on the religious past of the Lutheran community of Rösnitz (today's Polish name Rozumice) in Upper Silesia. This village is situated on the border with today's Czech Republic. Today it is a place of remembrance of the continuity of Protestant tradition, including pre-reform movements, since the 15 th century.

The continuity of the Lutheran denomination of the community since 1523 of the, which the author's research has shown, contradicts the generalized thesis of total recatholization of Upper Silesia. This article highlights one issue of the memorial site - the diversity of the Protestant tradition shown by the research of the past of this Lutheran community. This diverse tradition consists of pre-reformation Christian movements, including the Moravian Brothers, with whom the inhabitants of Rösnitz had already established contacts before the end of the 15th century. In the beliefs of this community, there are also themes characteristic for Waldensians who were known in Silesia. These movements prepared Rösnitz dwellers for the acceptance of Lutheranism. During the counterreformation period, 
the community did not undergo a recatholization. Later, Pietism strongly influenced the area, Count Ludwik von Zinzendof himself visits Rösnitz, where he speaks to the many gathered there from the surrounding villages. It even came to a split in this so far united municipality, which resulted in the emmigration of followers of Unita Fratrum to Herrnhut.

Keywords: Reformation, Lutherans, Upper Silesia, Hussites, Moravian Brothers, Pietism, Herrnhut 